\title{
Greenwater, Marine Bacillus subtilis HS1 Probiotic and Synbiotic Enriched Artemia and Rotifers Improved European Seabass Dicentrarchus labrax Larvae Early Weaning Length Growth, Survival, Water and Bacteriology quality
}

\author{
Salem Ahmed Md. ${ }^{1,}{ }^{*}$, Nour A. M. ${ }^{2}$, Srour T. M. ${ }^{3}$, Assem S. S. ${ }^{1}$, Ibrahim H. A. ${ }^{4}$, El-Sayed H. S. ${ }^{1}$ \\ ${ }^{1}$ Fish Reproduction \& Spawning Lab., Aquaculture Division, National Institute of Oceanography \& Fisheries (NIOF), Quiet Bay Castle, \\ El-Anfoshy, Alexandria, Egypt \\ ${ }^{2}$ Animal and Fish Production Dep., Faculty of Agriculture (El-Shatby), Alexandria University \\ ${ }^{3}$ Animal and Fish Production Dep., Faculty of Agriculture (Saba Basha), Alexandria University \\ ${ }^{4}$ Marine Microbiology Lab., Marine Environment Division, (NIOF), Alexandria, Egypt
}

Email address:

ahmedmdsalem@yahoo.com (Ahmed Md. Salem)

\section{To cite this article:}

Salem Ahmed Md., Nour A. M., Srour T. M., Assem S. S., Ibrahim H. A., El-Sayed H. S. Greenwater, Marine Bacillus subtilis HS1 Probiotic and Synbiotic Enriched Artemia and Rotifers Improved European Seabass Dicentrarchus labrax Larvae Early Weaning Length Growth, Survival, Water and Bacteriology quality. American Journal of Life Sciences. Special Issue: New Horizons in Basic and Applied Zoological Research. Vol. 3, No. 6-1, 2015, pp. 45-52. doi: 10.11648/j.ajls.s.2015030601.17

\begin{abstract}
The present study conducted in Fish Reproduction \& Spawning Lab., NIOF, Alexandria, Egypt. European sea bass Dicentrarchus labrax newly hatched larvae from $8 \mathrm{dph}$ to the $40 \mathrm{dph}$ was reared according to (Süzer et al., 2011). The 6 tanks was green water with $N$. salina Algal count not less than $300000 \mathrm{cell} / \mathrm{ml}$. The experimental treatments using green water using N. salina as positive control (G), green water plus marine probiotic bacteria (G+MP) and green water plus synbiotic $(\mathrm{G}+\mathrm{S}) .4$ hours enriched rotifers Brachionus plicatilis started from the $7^{\text {th }} \mathrm{dph}$ until the $14^{\text {th }} \mathrm{dph}$, the beginning of cofeeding on 6 hours enriched Artemia fransiscana (GSL) nauplii started and rotifers reduction started in the $18^{\text {th }} \mathrm{dph}$ and stopped from the $20^{\text {th }} \mathrm{dph}$ and artemia napulii fed alone until the $25^{\text {th }} \mathrm{dph}, 25 \mathrm{dph}$ larvae started feeding on artemia metanauplii and cofeeding with Orange ${ }^{\circledR}$ P $1 / 2$ Small microdiets with $100-200$ micron to $35 \mathrm{dph}$. From the $35^{\text {th }}$ dph artemia metanapulii stopped and larvae fed only on O.range $\mathbb{R}$ until the end of the experiment (the $40^{\text {th }} \mathrm{dph}$ ). The treatments were green water using Nanochlorapsis salina algae $(\mathrm{G})$, greenwater plus marine Bacillus subtilis HS1 Probiotic bacteria (G+MP) and greenwater plus synbiotic $(\mathrm{G}+\mathrm{S})$ in 30 1 tanks in duplicates. Microbiological measurements were performed in water samples in every larvae critical stage (7, 14, 21, 25, 35 and 40dph) for colony forming unit (CFU) of total bacterial count, Vibrio, Staphylococus, Aeromonas and Bacillus. Also water quality measurements were performed in the beginning of the experiment in $2 \mathrm{pm}$ and in the same time in the 7, 14, 21, 28,35 and 40 dph newly hatched larvae tanks. Finally, the results of the 40dph early weaned larvae showed significantly $(\mathrm{p}<0.05)$ higher final total length achieved by $(\mathrm{G}+\mathrm{MP})$ followed by $(\mathrm{G}+\mathrm{S})$ and the lower significant $(\mathrm{p}<0.05)$ recorded by $(\mathrm{G})$ treatment. The bacterial counts of the Aeromonas not detected in all treatments, the other bacterial counts showed promising results of $(\mathrm{G}+\mathrm{MP})$ and $(\mathrm{G}+\mathrm{S})$ than $(\mathrm{G})$ treatments in both inhibiting potentially pathogenic bacteria counts and also in improving the potentially useful bacterial counts.
\end{abstract}

Keywords: Marine Probiotic, Synbiotic, Larvae, Early Weaning

\section{Introduction}

Egypt, the $8^{\text {th }}$ world aquaculture producer is also the $1^{\text {st }}$ Mediterranean Sea, Arab and African aquaculture producer
(1). Egypt aquaculture production (986820 tons) divided to $61.88 \%$ tilapia, $11.55 \%$ mullets, $20.64 \%$ carps, $1.80 \%$ sea bass, $1.43 \%$ sea bream, $1.23 \%$ meager and $0.08 \%$ shrimps (2). Egypt marine aquaculture still depending on fry collected from natural resources (63 million fry) although Egypt had 6 
hatcheries producing 15.8 million fry, only 1.6 million were sea bass fry (2). In 2013, Egypt mass mortalities in Kafr El-Sheik and El- Behira governorates tilapia fish farms which diagnosed as A. hydrophilla outbreak and also, in Maryut Valley, Alexandria governorate in European seabass, gilthead seabream and meagre farms but with different reasons of high temperatures and low oxygen stress in seabass and meagre, 100 tons equals 7 million L. E. loses $(3,4)$ and because of Vibrio sp. outbreak in gilthead seabream after seabass and seabream wild collected fry were transported to this farms (3).

\section{Materials and Methods}

The present study conducted in Fish Reproduction \& Spawning Lab., NIOF, Alexandria, Egypt. European sea bass Dicentrarchus labrax newly hatched larvae from $8 \mathrm{dph}$ to the $40 \mathrm{dph}$ was reared according to (5).

\subsection{Fish Husbandry}

The larval tanks was green water with $N$. salina Algal count not less than $300000 \mathrm{cell} / \mathrm{ml}$. The experimental treatments using green water using $N$. salina as positive control $(G)$, green water plus marine probiotic bacteria $(\mathrm{G}+\mathrm{MP})$ and green water plus synbiotic $(\mathrm{G}+\mathrm{S}) .4$ hours enriched rotifers Brachionus plicatilis started from the $7^{\text {th }}$ dph until the $14^{\text {th }} \mathrm{dph}$, the beginning of cofeeding on 6 hours enriched Artemia fransiscana (GSL) nauplii started and rotifers reduction started in the $18^{\text {th }} \mathrm{dph}$ and stopped from the $20^{\text {th }} \mathrm{dph}$ and artemia napulii fed alone until the $25^{\text {th }} \mathrm{dph}$, $25 \mathrm{dph}$ larvae started feeding on artemia metanauplii and cofeeding with O.Range ${ }^{\circledR}$ P $1 / 2$ Small microdiets with $100-200$ micron to $35 \mathrm{dph}$. From the $35^{\text {th }} \mathrm{dph}$ artemia metanapulii stopped and larvae fed only on O.Range ${ }^{\circledR}$ until the end of the experiment (the $40^{\text {th }} \mathrm{dph}$ ). The treatments were green water using Nanochlorapsis salina algae (G), greenwater plus marine Bacillus subtilis HS1 Probiotic bacteria $(\mathrm{G}+\mathrm{MP})$ and greenwater plus synbiotic $(\mathrm{G}+\mathrm{S})$ in 301 tanks in duplicates.

\subsection{Measurements of Length Growth}

Growth of larvae were measured of total length (TL) to nearest $0.1 \mathrm{~mm}$. were carried out using binocular light research microscope with graded eye piece. Fish larvae samples were measured at the beginning in $7 \mathrm{dph}$ also, at the end of the study in 40dph), length growth parameters were performed. Fish survival rate were calculated according to (6) and average daily gain or increase in length were according to (7) and specific growth rate in length were according to (8).

\subsection{Measurements of Water Quality}

Water quality measurements were carried out biweekly using Hanna ${ }^{\circledR}$ HI9828 Water quality portable electric device were done in water quality in the beginning of the experiment in $2 \mathrm{pm}$ and in the same time in the $7,14,21,28,35$ and 40 dph newly hatched larvae tanks and the elctrolid device was genteelly putted in the bootom of the experimental tanks away from the air stone and water quality measurements are Dissolved Oxygen \% (DO\%), Dissolved Oxygen as $\mathrm{mg} / \mathrm{L}$ (DO $\mathrm{mg} / \mathrm{L}$ ), $\mathrm{pH}, \quad$ Salinity as part per thousand (ppt),Conductivity and Total Dissolved Solids (TDS).

\subsection{Microbiological Measurements}

\subsubsection{Counting the Bacterial Groups}

Microbiological measurements were performed in water samples in every larvae critical stages $(7,14,21,25,35$ and $40 \mathrm{dph}$ ) for colony forming unit (CFU) of total bacterial count, Vibrio, Staphylococus, Aeromonas and Bacillus were done in the Microbiology Lab., Marine Environment Division, NIOF., Serial dilutions from $10^{-2}$ through $10^{-6}$ were made using filtered sterilized sea water. A portion $(0.1 \mathrm{ml})$ from each appropriately diluted sample was used to inoculate plates prepared with seawater agar for total bacterial counting. Plates were incubated at $30^{\circ} \mathrm{C}$ for $24 \mathrm{~h}$. Plates of five selective media were inoculated with $1 \mathrm{ml}$ of appropriately dilution sample for counting the different bacterial groups: total bacterial count, Vibrio, Staphylococus, Aeromonas and Bacillus.

\subsubsection{Chemicals and Media}

All chemicals used for biochemical tests and extraction of antimicrobial activity were of pure grade and purchased from Sigma chemicals, USA. Ingredients of media were all of analytical grade and obtained from recognized chemical suppliers (mainly Oxoid Co.). Media used throughout the work are described below. The composition is given in $\mathrm{gl}^{-1}$. The $\mathrm{pH}$ value of the media was adjusted to 7.5 prior to sterilization. Autoclaving was occurred at $121^{\circ} \mathrm{C}$ for $15 \mathrm{~min}$.

\section{Media Used for Isolation and Enumeration of the Different Bacterial Groups}

a. Sea water agar

A selective medium by (9) used for determining total count bacteria. Peptone, 5; ferric phosphate, 0.1; agar, 15; sea water $1 \mathrm{~L}$.

b. Mannitol salt agar

A selective medium by (10) used for isolating Staphylococcus spp.: Peptone complex, 10; beef extract, 1; sodium chloride, 75; mannitol 10; phenol red, 0.025; agar 15.

c. Thiosulfate citrate bile salt sucrose agar (TCBS)

A selective medium by (11) used for isolating Vibrio spp.: Yeast extract, 5; peptone, 10; sodium thiosulfate, 10; sod-citrate, 10; Ox bile, 8; sucrose, 20; sodium chloride, 10; ferric chloride, 1; Bromothymol blue, 0.04; thymol blue, 0.04; agar, 14.

d. Aeromonas agar (Bile salts irgasan brilliant green agar (BSB) (LAB 167))

A selective medium for the isolation of Aeromonas spp: beef extract, 5; meat peptone, 5; xylose, 10; bile salts No. 3, 8.5; sodium thiosulphate, 5.44; irgasan, 0.005 ; brilliant green, 0.005; neutral red, 0.025; agar, 11.5. 


\subsection{Statistical Analysis}

Statistical analysis were performed using analysis of variance (ANOVA), differences among means were considered significant at $p<0.05$ multiple range of post hoc comparisons were performed using the least significant difference (LSD) to resolve the differences among the means of replication using basic statistics, STATISTICA ${ }^{\circledR}$ software for Windows (12).

\section{Results}

\subsection{Growth and Survival}

Finally, the results in Table 1 of the 40dph early weaned larvae showed significantly $(\mathrm{p}<0.05)$ higher final total length, total length gain, $A D G$ and $G \%$ achieved by $(\mathrm{G}+\mathrm{MP})$ treatment while $(\mathrm{G}+\mathrm{MP})$ and $(\mathrm{G}+\mathrm{S})$ treatments showed significantly $(\mathrm{p}<0.05)$ higher larval SGR $\%$ and survival $\%$.

Table 1. Effect of using green water, green water plus marine Probiotic and green water plus Synbiotic treatments on European seabass (D. labrax) newly hatched larvae length growth parameters in $\mathrm{mm}$.

\begin{tabular}{llll}
\hline Parameter & G & G+MP & G+S \\
\hline Initial TL (7DPH) & $4.182 \pm 0.195$ & $4.272 \pm 0.140$ & $4.162 \pm 0.063$ \\
Final TL (40DPH) & $9.500^{\mathrm{c}} \pm 0.767$ & $12.667^{\mathrm{a}} \pm 0.814$ & $11.383^{\mathrm{b}} \pm 0.618$ \\
Total length gain & $5.318^{\mathrm{c}} \pm 5.755$ & $8.395^{\mathrm{a}} \pm 0.765$ & $7.222^{\mathrm{b}} \pm 0.658$ \\
Total length ADG (mm/d) & $0.161^{\mathrm{c}} \pm 0.021$ & $0.255^{\mathrm{a}} \pm 0.023$ & $0.219^{\mathrm{b}} \pm 0.020$ \\
Total length SGR (\%/d) & $2.481^{\mathrm{b}} \pm 0.223$ & $3.290^{\mathrm{a}} \pm 0.184$ & $3.046^{\mathrm{a}} \pm 0.199$ \\
Total length G\% & $127.291^{\mathrm{c}} \pm 16.608$ & $196.590^{\mathrm{a}} \pm 17.155$ & $173.693^{\mathrm{b}} \pm 17.656$ \\
Final Survival \% & $7.592^{\mathrm{b}} \pm 3.949$ & $18.407^{\mathrm{a}} \pm 1.152$ & $20.111^{\mathrm{a}} \pm 2.768$ \\
\hline
\end{tabular}

Letters in the same row are for effects difference significance $(\mathrm{P}<0.05)$.

G: Green water, G+MP: Green water plus marine probiotic; G+S: Green water plus synbiotic.

TL: Total length, ADG: Average daily gain in mm per day, SGR: Specific growth rate in \% per day. G\%: Gain \%.

\subsection{Water Quality}

The results in Table 2 showed that the effect of using $(\mathrm{G}$, $\mathrm{G}+\mathrm{MP}$ and $\mathrm{G}+\mathrm{S})$ treatments on European seabass (D. labrax) $7,14,21,28,35$ and $40 \mathrm{dph}$ newly hatched larvae tanks dissolved oxygen \% $(\mathrm{DO} \%)$ in the $7 \mathrm{dph}$ tanks showed that the best significant $(\mathrm{P}<0.05)$ results achieved by $(\mathrm{G}+\mathrm{MP})$ and $(\mathrm{S})$. The 14, 35 and 40dph larvae tanks showed no significant differences while the best $\mathrm{DO} \%$ resulted by (G+MP). The 21and 28dph larvae tanks showed no significant differences while the best $\mathrm{DO} \%$ indicated by $(G)$. The dissolved oxygen in $\mathrm{mg} / \mathrm{l}$ (DO $\mathrm{mg} / \mathrm{l})$ in the $7 \mathrm{dph}$ larvae tanks showed no significant differences while the best DO $\mathrm{mg} / \mathrm{l}$ achieved by $(\mathrm{G}+\mathrm{S})$. The 14, 35 and 40dph larval tanks showed no significant differences while the best DO $\mathrm{mg} / \mathrm{l}$ resulted by $(\mathrm{G}+\mathrm{MP})$. The 21 and $28 \mathrm{dph}$ larvae tanks showed no significant differences while the best DO $\mathrm{mg} / \mathrm{l}$ achieved by $(\mathrm{G})$. The $\mathrm{pH}$ in the 7 and $14 \mathrm{dph}$ larvae tanks showed no significant differences while the best $\mathrm{pH}$ achieved by $(\mathrm{G}),(\mathrm{S})$ and (MP) with the same means. The 21 and 28dph larvae tanks showed no significant differences while the best $\mathrm{pH}$ resulted by $(\mathrm{G})$. The 35 and 40dph larvae tanks showed no significant differences while the best $\mathrm{pH}$ achieved by (MP) and $(\mathrm{G})$. The salinity in $\mathrm{mg} / \mathrm{l}$ (Sppt) in the 7dph larvae tanks showed that the biggest significant $(\mathrm{P}<0.05)$ Sppt achieved by $(\mathrm{G})$. The $14 \mathrm{dph}$ larvae tanks showed that the biggest significant $(\mathrm{P}<0.05)$ Sppt recorded by $(\mathrm{G}+\mathrm{S})$. The $21,28,35$ and 40dph larvae tanks showed no significant differences while the best Sppt achieved by (G).

The conductivity in $\mathrm{mS} / \mathrm{cm}$ (Cond.) in the $7 \mathrm{dph}$ larvae tanks showed that the biggest significant $(\mathrm{P}<0.05)$ Cond. achieved by $(\mathrm{G})$. The $14 \mathrm{dph}$ larvae tanks showed that the biggest significant $(\mathrm{P}<0.05)$ Cond. indicated by $(\mathrm{G}+\mathrm{S})$. The 21, 28 and 40dph larvae tanks showed no significant differences while the best Cond. achieved by $(\mathrm{G})$. The $35 \mathrm{dph}$ larvae tanks showed no significant differences while the best Cond. exhibited by $(\mathrm{G}+\mathrm{S})$. The total dissolved solids (TDS) in $\mathrm{ppm}$ in the $7 \mathrm{dph}$ larvae tanks showed that the biggest significant $(\mathrm{P}<0.05)$ TDS achieved by $(\mathrm{G})$. The $14 \mathrm{dph}$ larvae tanks showed that the biggest significant $(\mathrm{P}<0.05)$ TDS resulted by $(\mathrm{G}+\mathrm{S})$. The $21,28,35$ and $40 \mathrm{dph}$ larvae tanks showed no significant differences while the best TDS achieved by $(\mathrm{G})$. The Temperature in the 7, 14, 21, 35 and 40dph larvae tanks showed no significant differences while the biggest values achieved by $(\mathrm{G})$. The $28 \mathrm{dph}$ larvae tanks showed no significant differences while the best result achieved by $(\mathrm{G}+\mathrm{S})$.

\subsection{Bacterial Counts}

The Total bacterial counts (TBC) were determined in three treatments $(\mathrm{G}, \mathrm{G}+\mathrm{MP}$ and $\mathrm{G}+\mathrm{S})$ treatments on newly hatched larvae tanks water using nutrient agar medium. Results in Table 3 presented that the TBC in the water source used in the 6 tanks stocking showed the same counts $(1040 \mathrm{CFU} / \mathrm{ml})$. The TBC in the pre stocking samples of $2 \mathrm{dpf}$ eggs showed the same results $(1080 \mathrm{CFU} / \mathrm{ml})$. The TBC in the samples of algae used as source of green water showed the same results (3100 CFU/ml). The TBC in the 7, 14, 21, 25, 35 and 40dph larvae tanks showed that the highest significant $(\mathrm{P}<0.05)$ TBC achieved by (G). The Aeromonas counts (ABC) were determined in three treatments on newly hatched larvae tanks water using nutrient agar medium indicated that there was no ABC detected in all treatments. The Staphylococcus counts (SBC) were determined on newly hatched larvae tanks water using mannitol salt agar medium. The SBC in the pre stocking samples of $2 \mathrm{dpf}$ eggs showed the same counts (2050 $\mathrm{CFU} / \mathrm{ml})$.

The SBC in the samples of algae used as source of green water exhibited the same records $(3100 \mathrm{CFU} / \mathrm{ml})$. The SBC in the $7 \mathrm{dph}$ larvae tanks showed that the highest significant 
$(\mathrm{P}<0.05)$ SBC achieved by $(\mathrm{G})$. The SBC in the $14 \mathrm{dph}$ larvae tanks showed no significant difference while the highest SBC detected by (G+MP). The SBC in the $21 \mathrm{dph}$ larvae tanks showed no significant difference while the highest SBC achieved by $(\mathrm{G})$.

Table 2. Effect on European seabass (D. labrax) 7, 14, 21, 28, 35 and $40 \mathrm{dph}$ newly hatched larval tanks water quality parameters.

\begin{tabular}{|c|c|c|c|c|}
\hline Par. & Age & G & G+MP & $\mathbf{G}+\mathbf{S}$ \\
\hline \multirow{6}{*}{$\mathrm{DO} \%$} & $7 \mathrm{dph}$ & $93.95^{b} \pm 1.48$ & $102.00^{\mathrm{a}} \pm 0.00$ & $102.00^{\mathrm{a}} \pm 1.41$ \\
\hline & $14 \mathrm{dph}$ & $92.50 \pm 2.12$ & $99.00 \pm 5.66$ & $95.50 \pm 0.71$ \\
\hline & $21 \mathrm{dph}$ & $99.50 \pm 10.61$ & $94.00 \pm 15.56$ & $93.00 \pm 2.83$ \\
\hline & $28 \mathrm{dph}$ & $99.50 \pm 6.36$ & $99.00 \pm 8.49$ & $93.50 \pm 7.78$ \\
\hline & $35 \mathrm{dph}$ & $93.00 \pm 9.90$ & $93.50 \pm 3.54$ & $85.50 \pm 0.71$ \\
\hline & 40dph & $93.50 \pm 9.19$ & $100.50 \pm 0.71$ & $91.50 \pm 2.12$ \\
\hline \multirow{6}{*}{ DO mg/L } & $7 \mathrm{dph}$ & $7.55 \pm 0.07$ & $8.05 \pm 0.07$ & $8.16 \pm 0.32$ \\
\hline & $14 \mathrm{dph}$ & $7.35 \pm 0.07$ & $7.78 \pm 0.25$ & $7.50 \pm 0.28$ \\
\hline & $21 \mathrm{dph}$ & $7.80 \pm 0.85$ & $7.25 \pm 1.06$ & $7.35 \pm 0.21$ \\
\hline & $28 \mathrm{dph}$ & $7.40 \pm 0.57$ & $7.40 \pm 0.85$ & $7.10 \pm 0.42$ \\
\hline & $35 \mathrm{dph}$ & $7.10 \pm 0.85$ & $7.20 \pm 0.28$ & $6.50 \pm 0.14$ \\
\hline & 40dph & $6.90 \pm 0.71$ & $7.60 \pm 0.00$ & $6.85 \pm 0.07$ \\
\hline \multirow{6}{*}{$\mathrm{pH}$} & $7 \mathrm{dph}$ & $8.08 \pm 0.00$ & $8.08 \pm 0.01$ & $8.08 \pm 0.01$ \\
\hline & $14 \mathrm{dph}$ & $8.10 \pm 0.00$ & $8.10 \pm 0.14$ & $8.10 \pm 0.00$ \\
\hline & $21 \mathrm{dph}$ & $7.95 \pm 0.07$ & $7.90 \pm 0.14$ & $7.84 \pm 0.06$ \\
\hline & $28 \mathrm{dph}$ & $7.85 \pm 0.07$ & $7.80 \pm 0.14$ & $7.70 \pm 0.00$ \\
\hline & $35 \mathrm{dph}$ & $7.80 \pm 0.14$ & $7.80 \pm 0.00$ & $7.60 \pm 0.00$ \\
\hline & 40dph & $7.95 \pm 0.21$ & $7.95 \pm 0.07$ & $7.70 \pm 0.00$ \\
\hline \multirow{6}{*}{ Salinity $\mathrm{mg} / \mathrm{L}$} & $7 \mathrm{dph}$ & $37.77^{\mathrm{a}} \pm 0.05$ & $37.50^{b} \pm 0.00$ & $37.54^{b} \pm 0.05$ \\
\hline & $14 \mathrm{dph}$ & $36.60 \pm 0.00$ & $36.40^{\mathrm{b}} \pm 0.14$ & $36.80^{\mathrm{a}} \pm 0.00$ \\
\hline & $21 \mathrm{dph}$ & $36.60 \pm 0.14$ & $36.30 \pm 0.42$ & $36.60 \pm 0.00$ \\
\hline & $28 \mathrm{dph}$ & $36.90 \pm 0.14$ & $36.60 \pm 0.28$ & $36.70 \pm 0.00$ \\
\hline & $35 \mathrm{dph}$ & $37.65 \pm 0.21$ & $37.30 \pm 0.42$ & $37.15 \pm 0.07$ \\
\hline & 40dph & $37.90 \pm 0.14$ & $37.65 \pm 0.35$ & $37.40 \pm 0.00$ \\
\hline \multirow{6}{*}{$\begin{array}{l}\text { Conductivity } \\
\mathrm{mS} / \mathrm{cm}\end{array}$} & $7 \mathrm{dph}$ & $56.75^{\mathrm{a}} \pm 0.13$ & $56.33^{\mathrm{b}} \pm 0.04$ & $56.48^{\mathrm{b}} \pm 0.06$ \\
\hline & 14dph & $55.05 \pm 0.07$ & $54.88^{b} \pm 0.17$ & $55.30^{\mathrm{a}} \pm 0.00$ \\
\hline & 21dph & $55.10 \pm 0.14$ & $54.55 \pm 0.78$ & $55.00 \pm 0.00$ \\
\hline & 28dph & $55.45 \pm 0.21$ & $55.10 \pm 0.42$ & $55.25 \pm 0.07$ \\
\hline & $35 \mathrm{dph}$ & $56.55 \pm 0.21$ & $56.10 \pm 0.57$ & $55.85 \pm 0.07$ \\
\hline & 40dph & $56.85 \pm 0.21$ & $56.50 \pm 0.42$ & $56.00 \pm 0.00$ \\
\hline \multirow{6}{*}{ TDS ppm } & $7 \mathrm{dph}$ & $28.38^{\mathrm{a}} \pm 0.07$ & $28.14^{b} \pm 0.06$ & $28.22 \pm 0.01$ \\
\hline & 14dph & $27.55 \pm 0.07$ & $27.46^{b} \pm 0.11$ & $27.70^{\mathrm{a}} \pm 0.00$ \\
\hline & $21 \mathrm{dph}$ & $27.55 \pm 0.07$ & $27.40 \pm 0.14$ & $27.50 \pm 0.00$ \\
\hline & 28dph & $27.70 \pm 0.14$ & $27.55 \pm 0.21$ & $27.60 \pm 0.00$ \\
\hline & $35 \mathrm{dph}$ & $28.25 \pm 0.07$ & $28.00 \pm 0.28$ & $27.90 \pm 0.00$ \\
\hline & 40dph & $28.40 \pm 0.14$ & $28.20 \pm 0.28$ & $28.00 \pm 0.00$ \\
\hline \multirow{6}{*}{ Temperature ${ }^{\circ} \mathrm{C}$} & $7 \mathrm{dph}$ & $14.75 \pm 0.07$ & $14.70 \pm 0.00$ & $14.70 \pm 0.00$ \\
\hline & $14 \mathrm{dph}$ & $15.00 \pm 0.00$ & $15.00 \pm 0.00$ & $15.00 \pm 0.00$ \\
\hline & $21 \mathrm{dph}$ & $15.95 \pm 0.07$ & $15.85 \pm 0.07$ & $15.90 \pm 0.00$ \\
\hline & $28 \mathrm{dph}$ & $17.95 \pm 0.07$ & $17.75 \pm 0.21$ & $18.00 \pm 0.00$ \\
\hline & $35 \mathrm{dph}$ & $17.00 \pm 0.00$ & $16.85 \pm 0.21$ & $16.90 \pm 0.00$ \\
\hline & 40dph & $18.65 \pm 0.07$ & $18.55 \pm 0.21$ & $18.60 \pm 0.00$ \\
\hline
\end{tabular}

Letters in the same row are for effects difference significance $(\mathrm{P}<0.05)$.

The SBC in the 25dph larvae tanks showed no significant difference while the highest SBC exhibited by (G+MP). The $\mathrm{SBC}$ in the 35 and 40dph larvae tanks showed that the highest significant $(\mathrm{P}<0.05) \mathrm{SBC}$ resulted by $(\mathrm{G})$ and $(\mathrm{G}+\mathrm{S})$ The Vibrio counts (VBC) were determined on newly hatched larvae tanks water using nutrient agar medium. The VBC in the pre stocking samples of $2 \mathrm{dpf}$ eggs showed the same counts $(400 \mathrm{CFU} / \mathrm{ml})$. The VBC in the samples of algae used as source of green water exhibited the same records (40 $\mathrm{CFU} / \mathrm{ml}$ ). The VBC in the 7 and 21dph larvae tanks showed no significant differences while the highest VBC achieved by $(\mathrm{G}+\mathrm{S})$. The $\mathrm{VBC}$ in the $14 \mathrm{dph}$ larvae tanks showed no significant difference while the highest $\mathrm{VBC}$ indicated by $(\mathrm{G})$. The VBC in the 25dph larvae tanks showed no significant difference while the highest VBC resulted by $(\mathrm{G}+\mathrm{MP})$. The $\mathrm{VBC}$ in the $35 \mathrm{dph}$ larvae tanks showed that the highest significant $(\mathrm{P}<0.05) \mathrm{VBC}$ detected by $(\mathrm{G}+\mathrm{MP})$. The VBC in the 40dph larvae tanks showed that the highest significant $(\mathrm{P}$ $<0.05)$ VBC exhibited by $(\mathrm{G})$. The Bacillus counts (BBC) were determined in three treatments on newly hatched larvae tanks water on nutrient agar medium in the pre stocking samples of 2 dpf eggs showed the same counts (1925 $\mathrm{CFU} / \mathrm{ml})$. The BBC in the samples of algae used as source of green water exhibited the same records $(2000 \mathrm{CFU} / \mathrm{ml})$. The $\mathrm{BBC}$ in the 7, 14, 21 and 25dph larvae tanks showed that the highest significant $(\mathrm{P}<0.05) \mathrm{BBC}$ achieved by $(\mathrm{G}+\mathrm{MP})$. The $\mathrm{BBC}$ in the 35 and 40dph larvae tanks showed that the highest significant $(\mathrm{P}<0.05) \mathrm{BBC}$ exhibited by $(\mathrm{MP})$ and (S).

\section{Discussion}

The present study indicated that the results of using green water, green water plus marine $B$. subtilis probiotic and green water plus synbiotic on larvae length gains showed that better significantly results achieved by $\mathrm{G}+\mathrm{MP}$ and $\mathrm{G}+\mathrm{S}$ than $\mathrm{G}$ in most larvae body length and length gains parameters of $40 \mathrm{dph}$, showed potential application of them in these critical stages and these may be due to many factors and mechanisms such as positive effects of these treatments as supported by (13) who showed enhanced growth of gilthead seabream larvae using Bacillus sp. bacteria. These results supported by (14) who reviewed that the Bacillus mixture used in his study has been evaluated before as a candidate probiotic mixture, mainly for shrimp but also in fish larviculture. In those experiments, increased growth rates of shrimp and fish larvae and reduced Vibrio levels were obtained. B. subtilis and $B$. licheniformis were found to increase resistance to pathogenic Yersinia ruckeri in rainbow trout. In gilthead seabream, an improved cellular innate immune response was found when $B$. subtilis and L. delbrueckii were given. Reference (15) showed significant growth, SGR and survival of $S$. aurata larvae treated with probiotic. Larvae husbandry enhanced by Probiotic supplemented live food feeding. Significant results achieved by probiotic treated live food and live foods due to of Lactobacillus bacteria significant proportion changing in the gut flora the significant. This in agreement with $(16,17)$ studies on Indian white shrimp, F. indicus, and shrimp $P$. vannamei. Probiotics treated live food had more effective digestive enzymes due to bacterial colonization in the larval gut (15). Also suggested that the growth, husbandry and digestive process enhanced by probiotics through several beneficial microbial balance and specific enzymes activities mechanisms. This were in agreement with (18) study that recorded increased D. labrax larvae survival, growth, digestive enzyme activities when treated with live yeast Debaryomyces hansenii. 
European sea bass newly hatched larvae results, under high intial stocking densities of 50 fertilized egg per $\mathrm{ml}$, putting in considerations recent industerial larvae rearing protocols in the developed marine hatcheries had significant survival rates of using $\mathrm{G}+\mathrm{S}$ and $\mathrm{G}+\mathrm{MP}$ compared to $\mathrm{G}$ treatment in agreement with (19) whom reviewed that the development of an aquaculture industry relies on the profitability of its culture protocols. The methods utilized to raise a species not only have to be reliable and highly productive, as they have to be relatively inexpensive (19). This imposes several challenges to producers since a culture protocol that guaranties higher survival is not necessarily the most productive or profitable (19). For instance, higher stocking densities may generate lower survival, but be more productive than lower stocking densities (19). One of the greatest expenses for an aquaculture facility is the feeds, particularly the ones destined to the larvae (19).

Reference (20) indicated that the weaning period from Artemia to formulated feed decline in growth could also be partly explained by the hardness or the taste of the formulated feed or its lower palatability compared to high water content thin exoskeleton live foods. Reference (21) indicated that formulated feed not being preferred by gilthead seabream at the start of the co-feeding period. Reference (22) reported that some conducted studies have evaluated synbiotics impacts on survival, growth parameters or feed utilization. Rainbow trout treated for 12 weeks using $E$. faecalis and MOS/PHB had no survival rate differences (23). The Japanese flounder fed B. clausii and MOS/FOS was healthy and showed high survival, active ingestion and better growth (24). Reference (25) assessed commercial synbiotic, Biomin IMBO, (probiotic (E. faecium $5 \times 10^{11} \mathrm{CFU} / \mathrm{kg}$ ) and FOS as prebiotic), in three levels $0.5,1.0$ and $1.5 \mathrm{~g}$ per $\mathrm{kg}$ of commercial rainbow trout food. However, synbiotic treated rainbow trout fingerlings (25) showed significantly higher survival rate than control. The highest average of survival rate was observed in the $1 \mathrm{~g}$ per $\mathrm{kg}$ feed that was statistically different from lower, higher doses and the control groups. In B. subtillis/FOS or B. subtillis/chitosan synbiotics treated yellow croaker and cobia showed no survival rate differences $(26,27)$.

Table 3. Effect of using green water $(G)$, green water plus marine Probiotic (MP) and green water plus Synbiotic (S) treatments on European seabass (D. labrax) newly hatched larvae bacterial counts (CFU/ml).

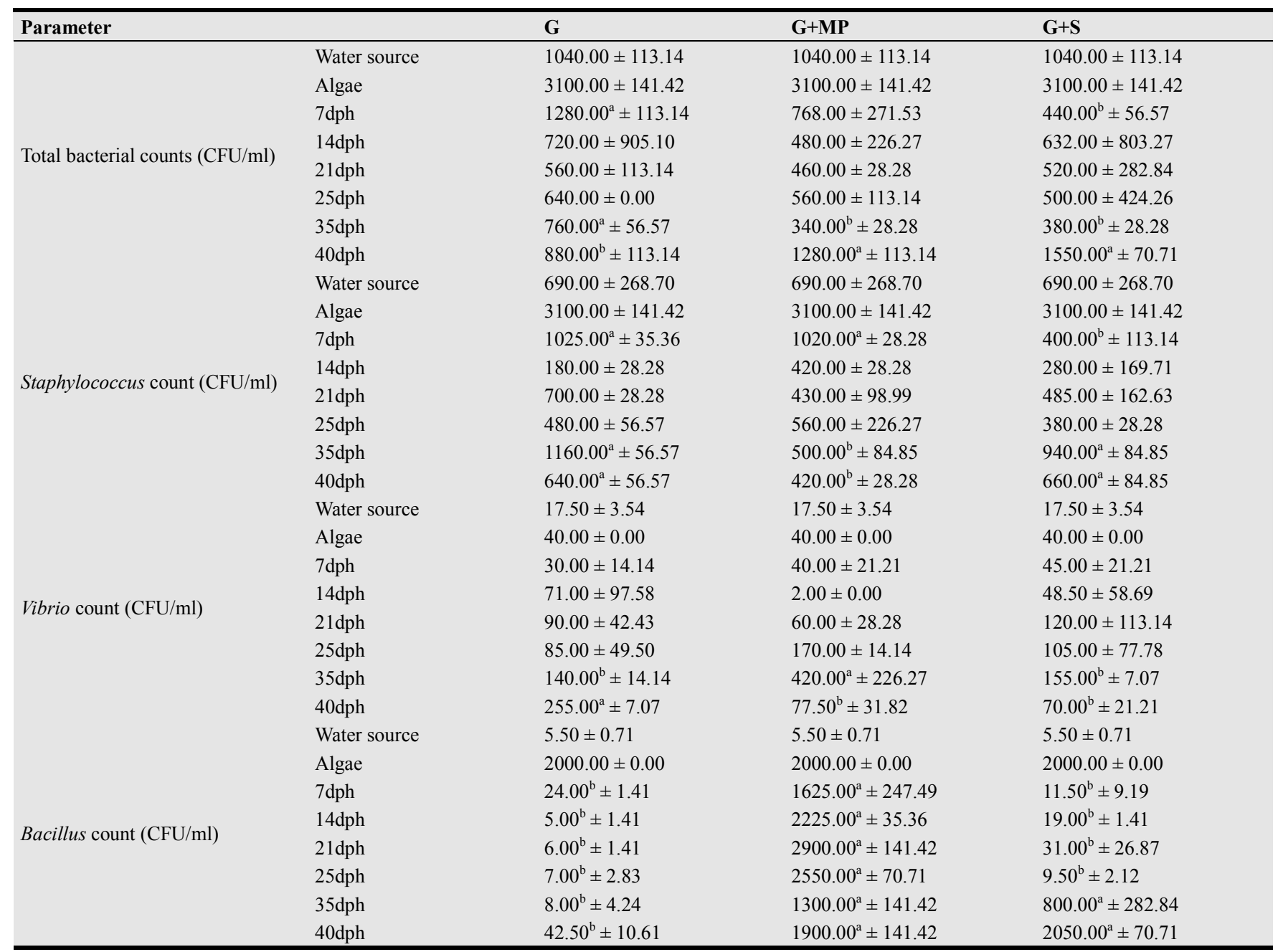

Letters in the same row are for effects difference significance $(\mathrm{P}<0.05)$.

G: Green water, G+MP: Green water plus marine probiotic; G+S: Green water plus synbiotic. 
The present study water quality results performances were within suitable limits for larval rearing tanks in agreement with $(8,28)$. Reference (29) showed that probiotics could significantly reduce the concentrations of nitrogen and phosphorus in pond water compared with the control in shrimp, $P$. vannamei ponds and the use of $B$. coagulans SC8168 in shrimp larvae as water additive had shown inconsistent results. In accordance with present obtained results (30) showed that there was no obvious effect of probiotic on the water quality. Newly isolated strains of $B$. subtilis, B. cereus and B. licheniformis were selected and evaluated as potential biological agents for the enhancement of the water quality in cultures of ornamental fish, and it was found that the selected isolates reduced together synergistically the level of pathogens and the concentrations of waste ions in vitro and in vivo and therefore, the strains were considered to be safe for use in ornamental aquaculture (31).

The bacterial counts of the potentially pathogenic bacteria such as Aeromonas sp., Staphylococcus sp. and Vibrio sp., or as potentially useful bacteria such as Bacillus $s p$ and total bacterial count in the three treatments showed that the potentially pathogenic bacteria reduced by MP followed by $S$ than $G$ similarly with (32) concluded that the bacteriocin-like compound produced by B. subtilis $\mathrm{SH} 1$ possesses an antimicrobial activity against a number of Gram-positive and Gram-negative bacteria, yeasts and fungi. The inhibitory effect of the compound against human pathogens such as $S$. aureus ATTC 6538 and P. aeruginosa ATTC 8739 suggests promising applications in the clinical field. The antifungal activity of the compound against some tested plant pathogens supports the utilization of $B$. subtilis $\mathrm{SH} 1$ as a good candidate for crop protection. (14) who reviewed that by adding a Bacillus mixture, larger changes in the bacterial communities between the initial and final experiment were observed. This implied that, by the end of the experiment, the Bacillus mixture probably was not able to maintain their initial composition. The subtle difference of cell wall composition of the two types of yeast strain, resulted in a nearly $40 \%$ difference in bacterial community similarity at the end of the experiment. The two types of yeast strains induced divergent change in the distribution of bacterial species. These results indicate changes in the composition and the evenness in a MC can be directed by the inputs of probiotics or different yeast strains. These changes might have an impact on the development of the intestinal microbiota of the fish larvae. Farmers often consider the probiotic as a replacement of chemicals and antibiotics, and as a result misused them as drugs and expected to see instant effects on the fish. Reference (33) reported that several authors indicated that probiotics effects and actions on enhancement of nutrition of aquacultured host through digestive enzymes production and better growth and feed efficiency, intestinal disorders prevention and feeds ingredients antinutritional factors pre-digestion. Reference (34) showed that probiotics germinate in the intestine, grow and produce digestive enzymes using carbohydrates. (14) reported that probiotics can be administered either as a food supplement or as an additive to the water. Probiotics increased P. vannamei and F. indicus shrimps growth performance (17). References (15, 35 ) indicated that the probiotics enhanced the immune responses and bacterial loading in aquatic organisms and environments. Probiotics treatments by live food and/or culture water decreased bacterial activity in $S$. aurata, $P$. dentatus, Scophthalmus maximus $(15,36,37)$.

Reference (14) showed that in vivo evaluations have proven that the Bacillus mixture has no deleterious effects on turbot. Furthermore, our experiments also confirmed the positive effects of the Bacillus mixture in terms of survival rate and reduction of Vibrio numbers, although the differences were not always significant. Yeasts, which are traditionally used as feed additives, have been promoted and used as probiotics and prebiotics in aquaculture (38). The yeast mutant had a positive effect (improved growth and protection against pathogen vibrios) on both rotifers and Artemia, under both gnotobiotic and open culture conditions. However, it was not known so far whether they have a beneficial or deleterious effect on fish larvae but showed a slight positive effect on the survival of turbot larvae, however the reduction on vibrios was not significant (14). Reference (14) reported that the socalled "microbial maturation of water" that delayed gut colonisation while increasing the survival rate of turbot larvae. An artificial enrichment of the flora with a lactic acid bacterium improved also the resistance of the larvae against a pathogenic vibrio. Reference (23) carried out for first time a challenge test in fish feed with synbiotics during 12 weeks. After 14 dpi with $V$. anguillarum all groups showed lower mortality than that control group, being significant in EM and EMP groups. Dietary B. subtilis supplementation in yellow croaker (26) during 10 weeks elevated the resistance to $V$. harveyi infection, but this response was not related with presence or concentration of FOS. No significant interactions were observed between dietary B. subtilis and FOS in the cumulative mortality after challenge. In (27) cobia fed diets supplemented with various levels of probiotic and chitosan for 56 days were challenged with $V$. harveyi. Post-challenge survival of fish was always significantly higher in high chitosan groups and increased at each chitosan level with the increase of $B$. subtilis supplementation level, which speculated chitosan and $B$. subtilis have a synergistic effect.

The obtained results of using green water algae, green water plus marine probiotic and green water plus synbiotic, which proved positive treatments could be explained by some factors in the contents of microalgae, the green water larval rearing conditioners and quality enrichment, also could be according to greenwater potentially useful bacteria which already colonized in the rearing water and adding marine bacilli probiotic or synbiotic containing multi bacilli and lactobacilli bacterial probiotic and bakery yeast fungal 
probiotic, multi prebiotics and enzymes, so the treatments plus green water are added value to the larval rearing and early weaning. These results in agreement of (13) who showed enhanced growth of gilthead sea bream larvae using Bacillus sp. bacteria and (39) who showed that growth hormone $(\mathrm{GH})$ concentrations in both pituitary gland and serum were low in vitamin B6-depleted rates. Reference (40) studied the effect of water treatment systems on gut microbial community (MC) in reared larvae of Atlantic cod and showed significant differences between water treatments on microbial communities supported. It is indicated that the process of stabilizing the microbial community of the rearing water results in enhancing larval growth and survival. (40) reported that early exposure to high bacterial densities may be important for immune tolerance. The zebra fish, it has been shown that the gut microbiota is necessary for the development of the immune system. Thus the establishment of a protective intestinal microflora will increase survival and growth of the fish larvae. Hence, the quality as well as quantity of early phase of several marine fish species highly depends on knowledge and possibility to control the complex interactions between the cultured organisms and the bacterial communities which develop at the mucosal surfaces, in the surrounding water, and the rearing systems. During the larvae stage, ingestion of bacteria may present antigens and be an important basis for the formation and development the immune system (40). This may result either in antigen priming or in development of immune tolerance to specific bacterial strains. These bacterial strains consist of aerobic, facultative anaerobic and obligate anaerobic forms and they are the principal colonizers in the GI tract of fish (40).

\section{References}

[1] FAO. 2012. The State of World Fisheries and Aquaculture. Rome, FAO. 209 pp.

[2] GAFRD, General Authority for Fish Resources Development. 2011. Fish statistics book. 107p.

[3] Salem, Ahmed Md. 2013. Marine fish reproduction and larvae rearing development using probiotic. Ph. D Thesis in Agricultural Sciences (Fish production), Animal and Fish production Department, Faculty of Agriculture (Saba Basha), Alexandria University, Alexandria, Egypt, 173p.

[4] El-Masry, H. 2013. Maryut vally fish farms lost 7 million L. E. Ahram, $10^{\text {th }}$ September, 2013 Journal, 46299. http://www.ahram.org.eg/NewsQ/231125.aspx.

[5] Süzer, C., Okan Kamaci, H., Çoban, D., Saka, Ş., Firat, K.; Karacaoğlan, A. 2011. Early weaning of sea bass (D. labrax) larvae: effects on growth performance and digestive enzyme activities. Turkish Journal of Fisheries and Aquatic Sciences, 11, 491-497.

[6] Castell, J. D.; Tiews, K. (Eds.) 1980. Report of the EIFAC, IUNS and ICES Working Group on the standardization of methodology in fish nutrition research. Humberg, Federal Republic of Germany, 21-23 March, 1979. EIFAC Tech. Pap.,
$36,24 \mathrm{pp}$.

[7] Garber, M. J., De Yonge, K. G., Byatt, J. C., Lellis, W. A., Honey field, D. C., Bull, R. C., Schelling, G. T.; Roeder, R. A. 1995. Dose response effects of recombinant bovine somatotropin (Posilac TM) on growth performance and body composition of two-year-old rainbow trout (Oncorhynchus mykiss). Journal of Animal Science, 73, 3216-3222.

[8] Nour, A. A., Zaki, M. A., AbdEl-Rahim, M. M.; Mabrouk, H. A. 2004. Factors affecting swim-bladder inflation, survival and growth performance of gilthead seabream Sparus aurata larvae: 2- water salinity. Egyptian J. of Aquatic Research, 30, 418- 428 .

[9] Zobell, C. E. 1946. Marine Microbiology. Waltham, MA: Chronica Botanica., 240 pp.

[10] Abo-Elela, G. M.; Farag, A. M. 2004. Bacteriological quality and metal contents of Diplodus vulgarus and Siganus rivulotus in the Eastern Harbour water: a comparative study of freshly harvested and market fish. Egyptian J. Aquatic Res., 30(A), 216-225.

[11] Kobayashi, T., Enomato, S., Sakazaki, R.; Kuwahara, S. 1963. A new selective medium for pathogenic Vibrios. TCBS agar (modified Nakanishi's agar). Japanese. J. Bacteriol., 18, 387-391.

[12] Stat Soft, Inc. 1995. STATISTICA for windows [Computer program manual]. Tulsa, OK: StatSoft, Inc., 2300 East 14th Street, website: http://www.statsoft.com.

[13] Ariğg, N., Süzer, C., Gökvardar, A., Başaran, F., Çoban, D., Yildirim, Ş., Kamaci, O., Firat, K.; Saka, Ş. 2013. Effects of probiotic (Bacillus sp.) supplementation during larval development of gilthead sea bream (Sparus aurata, L.). Turkish Journal of Fisheries and Aquatic Sciences, 13, 407-414.

[14] Qi, Z. 2008. The dynamics of microbial communities and probiotic supplements in the marine larviculture feed chain. $\mathrm{PhD}$ thesis, Ghent University, Belgium. 274P.

[15] Süzer, C., Çoban, D., Kamaci, H. O., Saka, S., Firat, K., Otgucuoglu, Ö.; Küçüksari, H. 2008. Lactobacillus spp. bacteria as probiotics in gilthead sea bream (Sparus aurata, L.) larvae: effects on growth performance and digestive enzyme activities. Aquaculture, 280, 140-145.

[16] Ziaei-Nejad, S., Rezaei, M. H., Takami, G. A., Lovett, D. L., Mirvaghefi, A. R.; Shakouri, M. 2006. The effect of Bacillus spp. bacteria used as probiotics on digestive enzyme activity, survival and growth in the Indian white shrimp Fenneropenaeus indicus. Aquaculture, 252, 516-524.

[17] Wang, Y. 2007. Effect of probiotics on growth performance and digestive enzyme activity of the shrimp Penaeus vannamei. Aquaculture, 269, 259-264.

[18] Tovar-Ramírez, D., Zambonino, I. J., Cahu, C., Gatesoupe, F. J., Vázquez-Juárez, R., 2004. Influence of dietary live yeast on European sea bass (Dicentrarchus labrax) larval development. Aquaculture, 234, 415-27.

[19] Figueiredo, J., Lin, J., Anto, J.; Narciso, L. 2012. The Consumption of DHA during Embryogenesis as an Indicative of the Need to Supply DHA during Early Larval Development: A Review. J. Aquaculture Res. Dev., 3, 140. 
52 Salem Ahmed Md. et al:: Greenwater, Marine Bacillus subtilis HS1 Probiotic and Synbiotic Enriched Artemia and Rotifers Improved European Seabass Dicentrarchus labrax Larvae Early Weaning Length Growth, Survival, Water and Bacteriology quality

[20] Almli, M. 2012. Effects of different live feed on larval growth and development in ballan wrasse (Labrus bergylta Ascanius, 1767): A metabolomics study. M. Sc. Thesies, NTNU, Trondheim, Norway.

[21] Conceição, L., Yúfera, M., Makridis, P., Morais, S.; Dinis, M. T. 2009. Live feeds for early stages of fish rearing. Aquaculture Research, 1-28.

[22] Cerezuela, R., Meseguer, J.; Esteban, M. 2011. Current knowledge in synbiotic use for fish aquaculture: A review. J. Aquac. Res. Development, 1- 7.

[23] Rodriguez-Estrada, U., Satoh, S., Haga, Y., Fushimi, H.; Sweetman, J. 2009. Effects of single and combined supplementation of Enterococcus faecalis, mannan oligosaccharide and polyhydrobutyric acid on growth performance and immune response of rainbow trout Oncorhynchus mykiss. Aquacult. Sci., 57, 609-617.

[24] Ye, J. D., Wang, K., Li, F. D.; Sun, Y. Z. 2011. Single or combined effects of fructo- and mannan oligosaccharide supplements and Bacillus clausii on the growth, feed utilization, body composition, digestive enzyme activity, innate immune response and lipid metabolism of the Japanese flounder Paralichthys olivaceus. Aquac. Nutr., 17, 902-911.

[25] Mehrabi, Z., Firouzbakhsh, F.; Jafarpour, A. 2012. Effects of dietary supplementation of synbiotic on growth performance, serum biochemical parameters and carcass composition in rainbow trout (Oncorhynchus mykiss) fingerlings. J. Anim. Physiol. Anim. Nutr., 96 (3), 474-481.

[26] Ai, Q., Xu, H., Mai, K., Xu, W.; Wang, J. 2011. Effects of dietary supplementation of Bacillus subtilis and fructooligosaccharide on growth performance, survival, non-specific immune response and disease resistance of juvenile large yellow croaker, Larimichthys crocea. Aquaculture, 317, 155-161.

[27] Geng, X., Dong, X. H., Tan, B. P., Yang, Q. H.; Chi, S. Y. 2011. Effects of dietary chitosan and Bacillus subtilis on the growth performance, non-specific immunity and disease resistance of cobia, Rachycentron canadum. Fish Shellfish Immunol., 31, 400-406.

[28] Zaki, M. A., Nour, A. A., AbdEl-Rahim, M. M.; Mabrouk, H. A. 2004. Factors affecting swim-bladder inflation, survival and growth performance of gilthead seabream Sparus aurata larvae: (1) rotifers Brachionus plicatilis consumption. Egyptian J. of Aquatic Research, 30, 406- 417.

[29] Wang, Y. B., Xu, Z. R.; Xia, M. S. 2005. The effectiveness of commercial probiotics in Northern White Shrimp (Penaeus vanname iL.) ponds. Fish. Sci., 71, 1034-1039.
[30] Zhou, Z., He, S., Liu, Y., Shi, P., Huang, G.; Yao, B. 2009. The effects of dietary yeast culture or short-chain fructo-oligosaccharides on the intestinal autochthonous bacterial communities in juvenile hybrid tilapia Oreochromis niloticus $9 \times$ Oreochromis aureus $\widehat{ }{ }^{2}$. J. World Aquacult. Soc., 40, $450-459$.

[31] Lalloo, R., Ramchuran, S., Ramduth, D., Gorgens, J.; Gardiner, N. 2007. Isolation and selection of Bacillus spp. as potential biological agents for enhancement of water quality in culture of ornamental fish. J. Appl. Microbiol., 103, 1471-1479.

[32] Ibrahim, H. A. 2007. Bacterial Community Structure in Suez Gulf: Distribution, molecular analysis and some applied aspects. PhD Thesies, Faculty of Science, Alexandria University.

[33] Verschuere, L., Rombaut, G., Sorgeloos, P.; Verstraete, W. 2000. Probiotic bacteria as biological control agents in aquaculture. Microbiol Mol. Biol. Rev., 64, 655-671.

[34] El-Haroun, E. R., Goda, A. S., Kabir, A. M.; Chowdhurry, M. A. 2006. Effect of dietary probiotic Biogen ${ }^{B}$ supplementation as a growth promoter on growth performance and feed utilization of Nile tilapia Oreochromis niloticus (L.). Aquacult. Res., 37, 1473-1480.

[35] Gatesoupe, F. J. 2007. Live yeasts in the gut: natural occurrence, dietary introduction, and their effects on fish health and development. Aquaculture, 267, 20-30.

[36] Planas, M., Pérez-Lorenzo, M., Hjelm, M., Gram, L., Fiksdal, I. U.; Bergh, Ø. 2006. Probiotic effect in vivo of Roseobacter strain 27-4 against Vibrio (Listonella) anguillarum infections in turbot (Scophthalmus maximus L.) larvae. Aquaculture, 255 323-333.

[37] Eddy, S. D.; Jones, S. H. 2002. Microbiology of summer flounder Paralichthys dentatus fingerling production at a marine fish hatchery. Aquaculture, 211, 9-28.

[38] Li, P.; Gatlin, D.M. III. 2005. Evaluation of the prebiotic GroBiotic $^{\mathbb{B}}$-A and brewer's yeast as dietary supplements for sub-adult hybrid striped bass (Morone chrysops $\times$ M. saxatilis) challenged in situ with Mycobacterium marinum. Aquaculture, 248, 197-205.

[39] Tryfiates, G. P. 1986. Pyridocal phosphate and metabolism. In: Dolphin, D. Poulson, R.; Avramovil, O. (Eds.), Vitamin B6, Pyridoxal Phosphate. Part B, 422-447. John Willy \& Sons, Inc. USA.

[40] Truong, T. M. H. 2012. Effect of water treatment systems on gut microbial community in reared larvae of Atlantic cod (Gadus morhua). M. Sc. Thesies, NTNU, Trondheim, Norway. 